Copyright (C) 2015 by Academic Publishing House Researcher

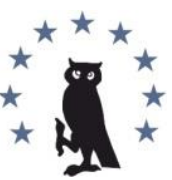

Published in the Russian Federation

European Researcher

Has been issued since 2010.

ISSN 2219-8229

E-ISSN 2224-0136

Vol. 100, Is. 11, pp. 702-710, 2015

DOI: 10.13187/er.2015.100.702

www.erjournal.ru

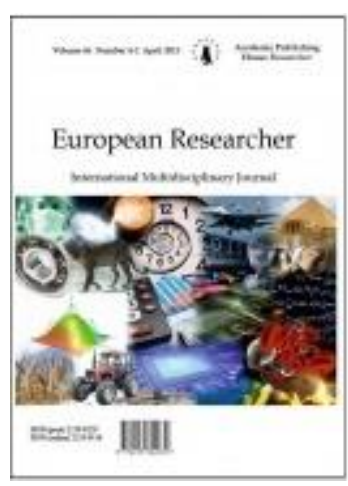

Historical sciences

Исторические науки

UDC 94(477)341.231(477):327“1920-1925”

\title{
Foreign-Policy Representative Office of Ukrainian SSR in International Relations (the Beginning of 1920th)
}

\author{
Oleksandr V. Danylenko
}

Taras Shevchenko National University of Kyiv, Ukraine

Doctor (History), Assosiate Professor

r. 349, Volodymyrska Str. 60, Kyiv 01601

E-mail: ovd@ua.fm

\begin{abstract}
The article reveals the main aspects of foreign political representation of the Ukrainian SSR in the beginning of 1920th. The paper proves that Ukraine was an active subject of the international relations. As the republican foreign ministry was eliminated and its power delegated to the Union's international agencies (after creation of Soviet Union) the Ukrainian SSR was presented at the international arena through its diplomats, representative organizations, participation in international projects, promotions, etc.

Keywords: international connections, foreign affairs, diplomatic relations, Ukrainian SSR, Soviet Union.

\section{Введение}

Изучая исторические события начала 1920-х годов, историки пытаются критически, но достаточно объективно, определить настоящий статус Украинской Социалистической Советской Республики (УССР) как субъекта международных отношений. В частности, выделяется экономический аспект отношений Российской Социалистической Федеративной Советской Республики (РСФСР) и УССР в 1917-1919 гг. в контексте политического противостояния, перераспределения межведомственных полномочий, централизации российско-советского экономического влияния в Украине [3]. Раскрывая проблему урегулирования административно-территориальных границ советской Украины, историки придерживаются принципов наследственности и последовательности сложных общественно-политических явлений, поэтому во внимание принимаются международные договора Украинской Народной Республики (УНР), УССР [1]. Становление дипломатических отношений УССР со странами Европы в начале 20-х гг. ХХ в. и определение личной роли $\begin{array}{llllll}\text { Х.Г. Раковского частично раскрыто в } & \text { работах } & \text { С. В. Кульчицкого [2; 4], }\end{array}$ В. Ю. Мельниченко [6].
\end{abstract}


Заданием этой научной статьи является прежде всего определение институционального статуса Народного комиссариата иностранных дел УССР, его организационно-функциональной эволюции в условиях формирования унитарного советского государства и определения реальных, а не продекларированных разными договорами и конституциями полномочий. Предметом исследования является республиканско-государственный статус политического представительства Украины за границей как полноценного субъекта международных отношений, анализ союзных и межреспубликанских законодательных актов, которые привели к утрате фактического и юридического веса УССР в самостоятельных экономических и культурных связях с окружающим миром.

\section{Материалы и методы}

Основными источниками для написания данной статьи стали документы и материалы партийных, советских, общественных организаций, хранящиеся в Центральном государственном архиве высших органов власти и управления Украины (ЦГАВО Украины), а также опубликованные в «Собрании узаконений Украины» (1921-1922 гг.).

В процессе исследования были использованы основные методы познания: проблемнохронологический, историко-генетический, ретроспективный, структурно-системный. Задействованы также методы из сферы юридических наук: формально-правовой и сравнительно-правовой. Рассуждения автора строятся на основе проблемнохронологического подхода, что позволило не только зафиксировать статичность событий и явлений, но и определить их взаимодействие, развитие и результаты.

\section{Обсуждение}

28 января 1919 г. Временное рабоче-крестьянское правительство Украины, учитывая фактор «...расширения территории и осложнения своих задач, признало необходимым реорганизоваться для наилучшего служения украинской революции» [4, с. 123]. Его главой и наркомом (министром) иностранных дел был Х. Раковский. Революция - украинская, власть - рабоче-крестьянская, а правительство - «временное». Статус временности зависел не только от размаха военных действий, а прежде всего от большевистского видения системы советской власти на просторах бывшей Российской империи. Принцип ее унитарности и неделимости был унаследован российскими коммунистами от самодержавия, о чем свидетельствуют центристские и унификаторские тенденции и политические усилия инициаторов так называемого военно-политического союза республик и объединительного движения народов бывших окраин за создание СССР. А призыв Х. Раковского «жить в мире и дружбе» относился тогда не только к рабочим и крестьянам советской России, а и других стран, поэтому правительство УССР призывало «...народы и правительства всех стран установить правильные дипломатические отношения с Украинской Социалистической Советской Республикой и обращается особенно к советским социалистическим правительствам России, Латвии, Белоруссии, Эстонии и Литвы с приглашением подписать тесный оборонительный союз против всяческих попыток ликвидировать власть рабочих и крестьян, установленную ценой таких тяжелых жертв» [4, с. 124].

Правительство УССР в лице наркома Х. Раковского заявило о себе как о субъекте дипломатических отношений, а дополнения «правильные» обозначало официальные и юридически выдержанные. Можно согласиться с известным украинским историком С. Кульчицким, выделявшим «дипломатические умения» Х. Раковского для «выхода на внешнеполитическую арену» УССР, а также его роль и место в ограничении «опасности оживления украинского сепаратизма». 31 января Х. Раковский предложил членам временного украинского правительства, которые находились в Москве, «...сделать формальное предложение Российской Советской Республике, а также другим советским республикам о создании оборонного союза под верховным военным и политическим руководством Российской Советской Республики» [4, с. 125]. Члены правительства УССР делегировались на конференцию, участники которой должны были рассмотреть вопрос об определении границ между советскими республиками.

Идея «оборонительного союза» от внешней угрозы, то есть интервенции, и представителей национальной политической силы украинской революции - войск УНР, 
стала потенциальной опасностью для потери внутреннего суверенитета украинского советского правительства. 4 марта 1919 г. III съезд КП(б)У принял политическое решение о признании конституции РСФСР, как образца для формирования конституции УССР, а 7 марта 1919 г. состоялось объединения Укрсовнархоза с ВСНХ РСФСР, предоставив России директивные полномочия. Позже объединились статистические службы. Не конституции республик или какие-либо институции самостоятельных советских государств, а VIII съезд РКП(б) предложил 19 марта 1919 г. принцип федеративного объединения государств, организованных «по советскому типу». Съезд даже признал за нациями «право на государственное отделение» [4, c. 142]. Так на практике действовал ленинский стратегический план «уступок националам», который реализовывался путем формальных обещаний о суверенитете, независимости, равности, братстве, свободе. Они играли функцию идеологических лозунгов, хотя были внесены в юридические акты и формально получили политико-правовой статус.

Начатое большевиками объединительное движение за создание союзного государства оказалось постепенным и неуклонным лишением украинского советского правительства государственных полномочий. Мотивируя необходимость борьбы с интервентами, ЦК РКП(б) и КП(б)У 8 апреля 1919 г. признали необходимым (в виде «уступки самостоятельным тенденциям») временное сохранение в советских республиках народных комиссариатов военных и морских дел и путей сообщения. Хотя они должны были действовать согласно директив соответствующих наркоматов РСФСР. Украинская железная дорога становилась неотъемлемой частью российской, руководимой Наркоматом путей сообщения из Москвы. 11 апреля российская сторона предложила разработать проект единой экспортно-импортной политики Украины и России, требуя от Х. Раковского принципиального согласия. 20 мая 1919 г. почтово-телеграфное, радиотелеграфное и телефонное дело, которое по ее организационно-техническим характеристикам было централизованным, отошло в сферу «общего управления» Наркомпочтеля РСФСР, несмотря на отсутствие какого-либо конституционного соглашения между республиками о федеративном устройстве. Отношения между ними, а точнее перераспределение полномочий, осуществлялось согласно принципа политической целесообразности.

Формирование военно-политического союза, инициированного ЦК РКП(б) и правительством РСФСР, достигло своего логического завершения и стратегического плана 1 июня 1919 г.: Всероссийский ЦИК издал декрет об объединении военно-морского командования, совнархозов, железнодорожного транспорта, финансов, наркоматов труда конкретных советских республик [4, с. 186]. 15 июня 1919 г. Х. Раковский послал М. Калинину телеграмму о том, что Украинский ЦИК принял резолюцию от 1 июня об объединении наркоматов, несмотря на предложения украинских эсеров о другой форме сотрудничества [4, с. 194].

21 июня 1919 г. ВУЦИК принял решение о расформировании Украинского фронта и передаче общего командования Реввоенсовету РСФСР [4, с. 196]. Объединение фактически завершилось, в результате чего получил функциональную, а не конституционную легитимность, принцип унитарности, то есть военного и политического верховенства в Украине ЦК РКП(б), ВЦИК и СНК РСФСР. Тенденция оглядываться на Москву начала проникать в другие наркоматы.

Статус республиканского и самодеятельного внешнеполитического ведомства формально сохранял Народный комиссариат иностранных дел УССР. Его функциональная самостоятельность в некоторой мере определялась сочетанием должности главы правительства и наркома иностранных дел в лице Х. Раковского, а также личные связи украинского лидера с «сотнями европейских политиков» [5, с. 293]. Пока продолжались военные действия между войсками Антанты, УНР, Польши против объединенных сил Красной армии - «дипломатические способности» украинского советского наркома иностранных дел не находили применения, а его принципиальная позиция не проявляла себя.

Функциональный статус украинской советской дипломатии проявил себя во время переговоров с Польшей, которые начались 17 августа 1920 г. в Минске. Делегатом от Украины на мирных переговорах был Н. Скрыпник, который сообщал 21 августа СНК УССР о том, что польская делегация не имела полномочий и желания вести переговоры, 
поскольку заявила об «инкорпорировании Украины Россией и о красном империализме» $[4$, c. 305]. Военные действия проходили на территории УССР, а войска УНР и Ю. Пилсудского не пребывали в России, и дипломатическая делегация была российскоукраинской, поэтому польская сторона не имела полномочий вести переговоры с УССР, которую считала частью РСФСР. Н. Скрыпник, информируя Х. Раковского и правительство Украины о такой политической коллизии, цитировал телеграмму наркома иностранных дел Г. Чичерина о подтверждении самостоятельности УССР. «Вполне правильно, - утверждал он, - что Украинская Республика не является частью Республики Российской. Даже тогда, когда федеративная связь между ними будет оформлена - это будет лишь тесная связь при сохранении независимости обеими странами. Украинская Советская республика не является в соответствии с разработанными проектами федеративной связи такой составной частью РСФСР, которой являются Башкирская и Татарская Республики. Самостоятельность Украинской Советской Республики является фактом, который польской делегации может быть неизвестен, но теперь ей нужно его подтвердить».

Заявление российского дипломата было политическим и декларативным, которое порадовало украинцев и частично успокоило поляков. Воспользовавшись передышкой, они перегруппировали силы и сдержали наступление Красной армии против них. 24 сентября российская сторона, а не украинская, предложила в Риге, куда переехали стороны, ускорить переговоры, оставив дискуссию о самостоятельности, и перейти к установлению польскоукраинской границы. Вмешательство советской России завершилось подписанием 18 марта 1921 г. Рижского мира, в результате чего за Польшей осталось 162 тис. кв. км украинской территории и 11 млн. чел. населения [1, с. 49].

В состав украинской делегации на переговорах с Польшей, кроме Н. Скрыпника, входили также Э. Квиринг и А. Шумский, которые имели совещательный голос. 6 декабря 1920 г. Э. Квиринг обратился к Х. Раковскому с предложениями по отношению полномочий Украины, а главное - обосновал странную формулу ее «суверенитета». Он считал, что Украина не была воюющей стороной в начале и в конце Первой мировой войны, а также в годы интервенции стран Антанты, поэтому проблема послевоенного урегулирования - это задача РСФСР. Приоритетным направлением для Украины он считал: взаимное признание (учитывая принцип самоопределения народов), отказ от взаимных расчетов долгов Российской империи, установление политических и военных гарантий, право гражданства, реэвакуация беженцев, налаживание торговли между странами, юридические гарантии общественных соглашений, восстановление почтовой, телеграфной связи, открытие дипломатических и консульских миссий [11, л. 11]. В частности, в начале января 1921 г. была открыта дипломатическая миссия Украинской ССР в России, которая имела официальное название на французском языке, подчеркивая таким образом международный статус: Mission Diplomatique de la Republique Socialiste des Soviets D'Ukraine en Russie [18, л. 14].

9 ноября 1921 г. Э. Квиринг направил партийным и советским органам власти в УССР докладную записку «О дипломатических представительствах», в которой высказался категорически против того, чтобы российский посол в прибалтийских странах и вообще был одновременно и представителем УССР, поскольку это противоречило суверенитету Украины и нормам международного права [11, л. 17]. Он настаивал на том, чтобы Украина имела собственные дипломатические представительства в разных странах мира, и обмен послами воспринимал як факт взаимного признания. К первоочередным и неотложным делам относил создание самодеятельных украинских представительств в Польше, Чехо-Словакии, Румынии, где проживала украинская диаспора - историческая и политическая. В то время Украина уже имела дипломатические отношения с Польшей, Латвией, Эстонией, Турцией, Австрией, вела переговоры с другими странами о налаживании связей. 17 октября 1921 г. ВУЦИК принял закон о порядке отношений с иностранными представительствами [7]. На протяжении первой половины 1922 г. появились законодательные акты о заграничных командировках служащих Украины [9, арт. 459], об институте уполномоченных НКИД УССР на территории УССР [8, ст. 236].

Централизаторские процессы, происходившие в 1921-1922 гг. по объединению разных наркоматов УССР и РСФСР, находили продолжение на дипломатическом фронте. Несмотря на обещанную Г. Чичериным самостоятельность УССР в международных отношениях, ее права и полномочия постоянно ограничивались. 11 июня 1921 г. СНК УССР делегировал 
своего представителя М. Полоза в Совет Труда и Обороны РСФСР [4, с. 359], хотя в России была украинская дипломатическая миссия.

Деятельность полпредств УССР за границей финансировал НКИД УССР. Так, 27 января 1922 г. коллегия Наркомата во главе с Х. Раковским утвердила смету полпредства Украины в Польше, Латвии и Литве. Между тем, основная дискуссия на коллегии развернулась вокруг конфликта между торговыми и политическими представительствами УССР и РСФСР в Варшаве и Риге. Коллегия решила «...дать директиву Бруку, указав, что Терлецкий является политическим представителем УССР в Латвии» [14, л. 2]. Фактически НКИД Украины объяснил статус и полномочия украинских представительств, а с другой стороны - высказал нежелательность объединения торговых представительств, потому что они принадлежали к компетенции Совнаркома Украины.

Тем не менее, игнорируя международные соглашения и собственные заявления о суверенитете советских республик и УССР в частности, советская Россия продолжала ограничивать украинское заграничное представительство. В 1922 г. международные инициативы Х. Раковского, соответственно и НКИД УССР, натолкнулись на сопротивление центра, потому что «...усилилась тенденция центрального партийно-государственного аппарата «автономизировать» независимые республики» [5, с. 296]. Так, стремление Украины обустроить торговое представительство в Италии было препарировано российской стороной, поэтому полпред РСФСР В. Воровский и дальше продолжал исполнять функции полномочного представителя УССР. В начале апреля 1922 г. НКИД УССР свернул дипломатическую миссию в Эстонии и Латвии, а представительские функции были переданы РСФСР [5, с. 296].

Дипломатическое ведомство Украины из прибалтийских стран оставалось только в Литве. «Политический представитель» Е. Терлецкий так оценил ситуацию, которая сложилась между украинскими и российскими советскими дипломатами на «Балтийском фронте»: «Выезжая сюда, - отмечал он, - я не предвидел, что буду иметь еще одну, самую тяжелую и тоже дипломатическую работу - установление взаимоотношений с полпредами РСФСР и тов. Ганецким, членом коллегии НКИД. По простоте своей рассчитывал на некоторое содействие - прежде всего политическое, а потом любое другое... Но предупреждающая рука тов. Ганецкого, который, вероятно, более ревностно относился к своему делу, чем я к Украине, еще до моего въезда в Прибалтику позаботился о «экстерриториальности» представительств, которые он протежирует. Послы получили целый ряд предупреждающих телеграмм, частных писем и т.д. по поводу того, что от украинцев нужно избавляться, им нечего делать, их необходимо подчинить себе и т.д. Предлагались практические средства - не давать помещения и денег, не давать возможности присылать своим шифром телеграммы через единственный на Москву провод, не предоставлять бесплатных услуг и тому подобное. Мне стыдно писать об этом, но вместе с тем возмутительно видеть, куда направлено внимание у руководителя прибалтийской политики, когда вместе с тем есть целый ряд просчетов, по заявлениям тех же полпредов, по важным политическим вопросам» [5, с. 296]. Исчерпывающая и судьбоносная характеристика - доказательство двойных дипломатических стандартов правительства советской России по отношению к украинским представительствам.

Украинская советская дипломатия, которую за границей представляли полпреды В. Ауссем (Германия), Ю. Коцюбинский (Австрия), А. Шумский (Польша), Е. Терлецкий (Прибалтика) и другие, - действовала согласно институционного статуса НКИД УССР, его полномочий, а также международных соглашений. 13 января 1922 г. коллегия рассмотрела вопрос о ратификации договоров с миссией Нансена, Американской администрацией помощи (AРA), назначила Т. Дука полпредом при иностранных организациях помощи голодающим в Украине, о возвращении австрийских граждан на родину, о делегировании Ю. Коцюбинского для подписания соглашения с Дальневосточной республикой [12, л. 110]. Украина официально была субъектом международных отношений, выполняя соответствующие обязательства.

Внешняя политика РСФСР определялась компартийным руководством, а ЦК КП(б)У был лишь областной организацией РКП(б), поэтому исполнял партийные директивы центра. НКИД РСФСР, если принимать во внимание его функциональные принципы согласно «Положения о НКИД РСФСР» от 6 июня 1921 г., налаживал «...политические 
отношения правительства РСФСР с правительствами государств, которые не входили в состав РСФСР» [13, л. 27]. Наркомат «защищал политические и экономические интересы РСФСР» и «российских советских» граждан, выдавал паспорта и визы, но был исключительно республиканским органом власти. Украина не имела федеративного соглашения с РСФСР, а НКИД в 1922 г. еще не принадлежал к категории объединенных, то есть «автономизированных» или унифицированных, поэтому прав был Е. Терлецкий, когда писал X. Раковскому об «экстерриториальности» и недопустимости вмешательства в работу украинских представительств в Прибалтике.

Наступление на суверенные права УССР (в лице торгпредставительств независимой советской республики) со стороны РСФСР имело некоторый экономический, но, главное, политический интерес - исключить возможности расширения деятельности внешнеполитического ведомства Украины. Этим объясняется давление на представителя УССР в Германии В. Ауссема, который ментально не был украинцем, но ответственно исполнял делегированные ему полномочия, а также промедление с открытием дипломатической миссии УССР в Турции.

Вторая половина 1922 г., которая выделялась активизацией унификаторских тенденций, коснулась также и полномочий УССР во внешней деятельности. Положение о НКИД УССР, проект которого был подан на рассмотрение ВУЦИК 10 сентября 1922 г., декларировало статус, полномочия и функции этого государственно-представительского наркомата. Он должен был заниматься политическими отношениями с иностранными государствами, хлопотами о защите украинских граждан в их делах за границей, обеспечением прав иностранных граждан в Украине, содействовать украинской торговле и «вообще украинским интересам» [13, л. 3].

Это были базовые принципы внешней политики правительства УССР, имеющие межгосударственный и социогуманитарный характер. Наркомат имел собственную структуру (коллегию, дипломатический отдел, экономически-правовой отдел, бюро по обслуживанию иностранцев, заграничный отдел РАТАУ, полномочные представительства (посольства), генеральные консульства, вице-консульства), то есть был самодостаточным. ВУЦИК, по ходатайству Совнаркома, назначал Наркома, который был «...полномочным представителем УССР в ее внешних отношениях и действующим в этих отношениях от ее имени» $[13$, л. 3]. Ведомство имело собственную гербовую печать. Без его разрешения ни одно государственное учреждение не имело права командировать за границу лиц с частными или служебными делами.

Именно НКИД УССР, а не какая-либо другая советская институция, осуществлял: присмотр и руководство деятельностью дипломатических и консульских представительств Украины и должностных лиц, находящихся за границей в служебных командировках; дипломатические отношения и переговоры с иностранными государствами как по отдельным, вызванным текущими государственными делами, так и согласно соглашениям, договорам, конвенциям; редактирование договоров и передача их на утверждение органам верховной власти УССР; руководство и присмотр за их исполнением; сбор информации о политической и экономической жизни заграничных стран и информирование соответствующих органов власти в Украине, содействие иностранным представительствам.

Появление этого «Положения» должно было напомнить унификаторам о суверенитете УССР и о республиканском институционном статусе внешнего наркомата. Однако остановить аннексию его функциональных полномочий со стороны центра было невозможно. 2 января 1922 г. НКИД РСФСР взял на себя инициативу устанавливать порядок международной деятельности Красного Креста Украины, а политбюро ЦК КП(б)У поручило 23 января президиуму ВУЦИК принять решение об участии Украины в работе Генуезской конференции и считать «...безусловно необходимым единый дипломатический фронт Советской Федерации по возможности в форме единой делегации, которая будет представлять все советские республики» [4, с. 390]. Так Украина была отстранена от переговорного процесса. Представительский статус НКИД УССР был проигнорирован. Украину представлял не нарком иностранных дел Х. Раковский, а демонстративно выдвинутый центром полномочный представитель УССР в Москве М. Полоз.

Принцип единства «дипломатического фронта», предложенный партийным органом политбюро ЦК КП(б)У, означал ползущую унификацию работы украинского 
внешнеполитического ведомства, его ограничения и реорганизацию. 19 мая 1922 г. СНК УССР предложил «всем наркоматам» на протяжении десяти дней разработать проекты положения о взаимоотношениях с соответствующими наркоматами РСФСР, а 6 октября 1922 г. ЦК РКП(б) признал необходимым подписание договора между республиками о формировании союзного государства - CССР [4, с. 417]. Политически было заявлено об объединении самодостаточных наркоматов и создании союзного правительства, а также о появлении института его уполномоченных в республиканских наркоматах. Вместо полноценного и самостоятельного НКИД УССР должен был появиться Уполномоченный НКИД СССР при СНК УССР с абсолютными директивными функциями. Одновременно при структурных подразделениях союзного внешнеполитического ведомства за рубежом допускалось существование разных представительств советских республик.

Самостоятельными считались те наркоматы, которые не подлежали объединению, то есть образования, земледелия, юстиции, социального обеспечения. 25 ноября 1922 г. между Наркомвнешторгом РСФСР и Укрвнешторгом было подписано соглашение о создании единого представительства, которое бы осуществляло экономическую и экспортноимпортную деятельность. В странах, где Украина имела особый экономический интерес, Укрвнешторгу разрешалось создавать в составе объединённого представительства аппарат своего уполномоченного, но он действовал с разрешения руководителя объединенного представительства [4, с. 437]. Украина утратила и внешнеэкономическую сферу государственной политики, которую у нее отобрали.

30 декабря 1922 г. был подписан договор о создании СССР, согласно которому не предвиделось функционирование республиканских наркоматов иностранных дел, поскольку возник НКИД СССР. Он был уполномочен представлять всю страну на международной арене, формировал новый дипломатический корпус и реализовывал внешнюю политику правящей партии, потеряв право на самодеятельность, которое формально имел НКИД УССР до ликвидации.

Заграничная пресса, особенно эмигрантская, уже осенью 1922 г. заговорила о фактической утрате Украиной кратковременного суверенитета внешнего ведомства. Газеты «Вечернее чешское слово», «Трибуна» писали о конце самостоятельности советской Украины, которую поглотила советская Россия.

Республиканская номенклатура, которая после создания союзного государства утратила свой полномочный статус, потому что местные наркомы объединенных наркоматов должны были выполнять распоряжения центра, пыталась сохранить за собой некоторые права. 2 февраля 1923 г. состоялось заседание комиссии, которая рассмотрела проект положения об объединенных наркоматах $[15$, л. 1]. Eе участниками были Х. Раковский, О. Рейхель, В. Касандров, С. Брон, М. Владимирский, П. Сологуб, В. Яковлев. Они предложили такую редакцию статьи первой «Положения о НКИД»: «Для обеспечения интересов Украинской республики при проведении внешней союзной политики, в состав Коллегии НКИД СССР привлекается один член, персональная кандидатура которого выдвигается Украинским СНК и утверждается СНК СССР на общих основаниях» [15, л. 1]. Уполномоченного НКИД СССР при СНК УССР назначала Москва, но по согласованию с украинским правительством. Комиссия также предложила внести в текст будущей конституции СССР положение о праве Украины иметь дипломатических агентов и выступать на международной арене вне союзного ведомства по некоторым вопросам через представительства.

Текст союзного договора и Конституции СССР обсуждали на протяжении первой половины 1923 г., вносили дополнения, но от этого уже не зависела судьба наркомата иностранных дел Украины. 10 февраля 1923 г. эти документы были рассмотрены СНК УССР. Идея о предоставлении Малому СНК СССР функций постоянного органа с внесением в союзный договор была отклонена, ограничившись текстом декларации о создании СССР. 19 мая 1923 г. проведено очередное объединенное заседание комиссии, которая приняла договор о создании СССР, но с внесением изменений: о защите суверенитета республик, о смене их внутренних границ исключительно при согласии республик, о сохранении за ними права отношений с соседними странами по административным, образовательным, судебным, хозяйственным вопросам с возможностью подписывать соответствующие соглашения. 
6 июля 1923 г. вторая сессия ЦИК СССР утвердила Конституцию СССР [4, с. 564], которая юридически и окончательно устранила какие-либо внешнеполитические функции НКИД УССР. 14 июля 1923 г. Х. Раковский обратился к странам Европы, указав на тот факт, что конституция СССР ограничивает суверенитет УССР соответствующими положениями, а НКИД УССР передал союзному ведомству права и полномочия, обязательства по международным соглашениям и т.п. [10, л. 321]. 20 июля 1923 р. формально действующий НКИД УССР рассмотрел и фактически принял к исполнению положение о Уполномоченном НКИД СССР в УССР, в котором были изложены его полномочия: выдача виз на въезд в страну иностранцам по дипломатическим и служебным паспортам, присмотр за украинским правительством по вопросу соблюдения прав иностранцев и исполнением международных соглашений, решение в центре украинских проблем. 20 июля 1923 г. состоялось одно из последних заседаний коллегии НКИД УССР, которое постановило прекратить деятельность представительств НКИД УССР за границей с 5 августа [10, л. 321]. Коллегия назначила В. Ауссема советником Полномочного представительства СССР в Берлине, М. Левицкого - в Вене, Н. Калюжного - в Праге. Консульства иностранных государств в Украине открывались с одобрения НКИД СССР, а за границей УССР имела миссии при полпредставительствах СССР. Осенью 1923 г. НКИД УССР перестал существовать.

\section{Выводы}

Внешнеполитическое представительство УССР имело полномочные права до осени 1923 г., выступая субъектом международных отношений, хотя достаточно активно исполняла функции посредника и российская советская дипломатия. Самодеятельность НКИД УССР в меньшей мере зависела от авторитетной личности Х. Раковского, а была определена временными уступками «националам» со стороны центра, статусом республиканского наркомата. Украина подписала много международных соглашений, имела свои представительства более чем в десяти странах, то есть проводила внешнюю политику, согласовывая или не согласовывая с Москвой те или иные вопросы. Создание СССР означало по сути прекращение Украиной функций самостоятельного субъекта международных отношений, которые переходили к НКИД СССР, а республиканское внешнеполитическое ведомство было ликвидировано. Ограничения касались также и деятельности торговых представительств. Хотя в 1920-ые гг. уровень международной правосубъектности Украинской ССР значительно снизился, тем не менее, она инерционно оставалась еще участником многих международных проектов, акций, операций.

\section{Примечания:}

1. Боєчко В., Ганжа О., Захарчук Б. Кордони України: історична ретроспектива та сучасний стан / В. Боєчко, О. Ганжа, Б. Захарчук. К.: Основи, 1994. 168 с.

2. Волковинський В. М., Кульчицький С. В. Християн Раковський. Політичний портрет / В. М. Волковинський, С. В. Кульчицький. К.: Політвидав, 1990. 266 с.

3. Єфіменко Г. Г. Взаємовідносини Кремля та радянської України: економічний аспект (19171919 рр.) / Г. Г. Єфіменко. К.: Ін-т історії України, 2008. 230 с.

4. Коммунистическая партия - вдохновитель и организатор объединительного движения украинского народа за образование СССР. Сборник документов и материалов, изд. второе, доп. / Ред. кол.: И. Д. Назаренко (руковод.), Н. Р. Доний, В. В. Кузьменко и др.; состав. П. М. Павлюк, П. П. Бачинский, Л. И. Лозенко и др. К.: Политиздат, 1972. 678 с.

5. Кульчицький С. Комунізм в Україні: перше десятиріччя (1919-1928) / С. Кульчицький. К.: Основи, 1996. 396 с.

6. Мельниченко В. Е. Раковский против Сталина / В. Е. Мельниченко. М.: Знание, 1991. 64 с.

7. Собрание Узаконений Украины, 1921, №21.

8. Собрание Узаконений Украины, 1922, №14.

9. Собрание Узаконений Украины, 1922, №29.

10. Центральный государственный архив высших органов власти (ЦГАВО Украины), ф.4, оп. 1, д. 12.

11. Центральный государственный архив высших органов власти (ЦГАВО Украины), ф. 4, оп. 1, д. 14. 12. Центральный государственный архив высших органов власти (ЦГАВО Украины), ф. 4, оп. 1, д. 15. 13. Центральный государственный архив высших органов власти (ЦГАВО Украины), ф.4, оп. 1, спр. 32. 
д. 53. д. 56.

14. Центральный государственный архив высших органов власти (ЦГАВО Украины), ф. 4, оп. 1,

15. Центральный государственный архив высших органов власти (ЦГАВО Украины), ф. 4, оп. 1, д. 489.

16. Центральный государственный архив высших органов власти (ЦГАВО Украины), ф. 4, оп. 1,

\title{
References:
}

1. Bojechko V., Ganzha O., Zaharchuk B. Borders Of Ukraine: historical retrospective and the current state/ V. Bojechko, O. Ganzha, B. Zaharchuk. K.: Basics, 1994. 168 s. (In Ukrainian).

2. Volkovynskyj V. M., Kulchytskyj S. V. Hrystyjan Rakovskyj. Political portret / V. M. Volkovynskyj, S. V. Kulchytskyj. - K.: Politpublish, 1990. 266 s. (In Ukrainian).

3. Jefimenko G. G. Relations of Kremlin and Soviet Ukraine: economical field (1917-1919 yy.) / G. G. Jefimenko. K.: Institut of history of Ukraine, 2008. 230 s. (In Ukrainian).

4. Communist party - inspirer and organizer of unification movement of Ukrainian people for organizing Soviet Union. Collection of documents and materials, second edition, compl. / Ed. board.: I. D. Nazarenko (dir.), N. R. Donij, V. V. Kuzmenko etc.; staff: P. M. Pavlyuk, P. P. Bachynskyj, L. I. Lozenko etc. - K.: Politpublishing, 1972. 678 s. (In Russian).

5. Kulchytskyj S. Communism in Ukraine: first decade (1919-1928) / S. Kulchytskyj. K.: Basics, 1996. 396 s. (In Ukrainian).

6. Melnychenko V. E. Rakovskyj contrary to Stalin / V. E. Melnychenko. - M.: Knowledge, 1991. 64 s. (In Russian).

7. Collections of laws of Ukraine. 1921, №21.

8. Collections of laws of Ukraine. 1922, №14.

9. Collections of laws of Ukraine. 1922, №29.

10. Central state archive of the highest organizations of power of Ukraine (CDAVO Ukrainy). F. 4, l. 1, f. 12.

11. Central state archive of the highest organizations of power of Ukraine (CDAVO Ukrainy). F. 4, l. 1, f. 14.

12. Central state archive of the highest organizations of power of Ukraine (CDAVO Ukrainy). F. 4, l. 1, f. 15 .

13. Central state archive of the highest organizations of power of Ukraine (CDAVO Ukrainy). F. 4, l. 1, f. 32.

14. Central state archive of the highest organizations of power of Ukraine (CDAVO Ukrainy). F. 4, l. 1, f. 53.

15. Central state archive of the highest organizations of power of Ukraine (CDAVO Ukrainy). F. 4, l. 1, f. 56. f. 489 .

16. Central state archive of the highest organizations of power of Ukraine (CDAVO Ukrainy). F. 4, l. 1,

УДК 94(477)341.231(477):327“1920-1925”

\section{Внешнеполитическое представительство Украинской ССР в международных отношениях (начало 1920-х гг.)}

\author{
Александр Викторович Даниленко
}

Киевский национальный университет имени Тараса Шевченко, Украина

Доктор исторических наук, доцент

Украина, Киев 01601, ул. Владимирская 6о, к. 349

E-mail: ovd@ua.fm

Аннотация. Раскрываются основные аспекты деятельности внешнеполитического представительства УССР в начале 1920-х гг. Акцентируется внимание на том, что Украина была активным субъектом международных отношений в этот период. С момента ликвидации республиканского внешнеполитического ведомства и делегирования своих международных полномочий союзным ведомствам (после создания СССР) - Украинская ССР была представлена на международной арене через своих дипломатов, представительства организаций, путем участия в международных проектах, акциях и т.д.

Ключевые слова: международные связи, внешние отношения, дипломатические отношения, Украинская ССР, Советский Союз. 